\title{
ALL ROADS LEAD TO ROME
}

A review of Heikki E.S. Mattila's El Latín jurídico. Historia, uso internacional, problemas de comunicación.

(Ediciones Jurídicas Olejnik, Santiago de Chile, pp. 169, ISBN 978-956-392-822-8).

\section{Marcus GALDIA}

Dr.phil., Dr.iur., Associate Professor of Law

International University of Monaco

14, rue Hubert Clérissi

MC 98000 Monaco

mgaldia@monaco.edu

ORCID: https://orcid.org/000-0008-0490-5213

The old proverb Omnes viae Romam ducunt holds true at least in legal linguistics. Indeed, legal Latin as the language of the Roman law that formed our conceptual legal language cannot be avoided in research undertakings aiming at the understanding of the origins of our legal language. In this context, it is important to notice that the renowned legal linguist and specialist in the area of legal Latin, Professor Heikki E.S. Mattila published in 2020 an overview of the research into legal Latin, written in the Spanish language. 
Professor Mattila described the state of the art in the research into the language of the Roman law already in his magisterial Comparative Legal Linguistics, available in many editions and languages (cf. Mattila 2017) and in his multiple other publications. Most fundamental findings of his sustained efforts are now rendered in his El latín jurídico.

Professor Mattila's work on legal Latin and legal linguistics as well as the book as such are introduced for Latin American readers in a preface by David Efraín Misari Torpoco, the general director of the series Biblioteca de Latín Jurídico. In the same preface, a sketch of some issues relevant to the research into legal Latin in Latin America is provided as well. These remarks are particularly helpful for scholars working in other parts of the world as they enable the understanding of the background of legal Latin studies in Latin America.

Professor Mattila's book consists of six chapters and four appendices. Chapter One comprises a synopsis of the research into legal Latin and it indicates the specific approach that Mattila adapted for his book. In Chapter Two, the importance of the Roman law for the development of law in general is described. Chapter Three covers the history of legal Latin. Chapter Four discusses the relation between legal Latin and contemporary legal systems. Chapter Five covers legal Latin as a tool of communication and chapter Six brings conclusions. Finally, Appendix One brings the list of dictionaries of legal Latin, Appendix Two presents a broad bibliography, Appendix Three lists Latin expressions and maxims dealt with in the book, finally Appendix Four includes an analytic index that facilitates searches in the main text.

Mattila distinguishes multiple forms of legal Latin in contemporary legal languages. Our legal language is largely a borrowing from Latin, yet this regularity is not always directly visible in the legal terminology. Next to it, legal terminology and expressions formed entirely in Latin or translated into other languages are discussed as well. Moreover, Mattila deals strictly with legal Latin. This has the advantage that the research perspective remains within the ambit of the Roman law and within formations that succeeded it historically such as ius commune. However, the reviewer may also signal another approach that deals with Latin in legal texts in general, for instance also with medical terms. This is the case in the recent Hong Kong monograph written by Tsou and Chin (2021). Both paradigmatic choices mark the difference between legal-linguistic and purely linguistic approaches in this area of research. 
Professor Mattila's approach to legal Latin becomes clearer towards the epistemic background of the legal-linguistic research into legal Latin that has many roots. For the one, the traditional science of the Roman law focused on doctrinal issues and their historical developments. To clarify these problems, Roman Law studies needed access to the sources of the Roman law expressed in the Latin language. On the other side, teaching legal Latin was often reduced to acquiring skills that enable the translation of legal texts of the ancient Rome into other languages. Even very good textbooks on 'Latin for Jurists' do not transgress these glottodidactic limits (cf. Rezler 1984). Hence, both approaches to not research the legal Latin language as such but set other priorities. Beginning with Professor Mattila's studies the legal Latin is researched as what it is, namely as the language of the Roman law and the basis for legal systems developed on the fundamentals established by ancient Roman jurists.

The search for the appropriate approach to legal Latin studies reveals many problems. It starts with writing down the law. Incidentally, our initial proverb All roads lead to Rome was committed to writing first in the Middle Ages. Interestingly, also the fact that the ancient Romans committed their law to writing was an extraordinary event for the legal sciences and for legal linguistics. The idea to write down the law in its entirety was not new in the Roman antiquity, yet it seems that it was for the first time fully implemented by the ancient Romans. Its logical precondition has been the task to formulate law worth such an effort. Without the emergence of the legal science and the systematic inquiry into the principles and mechanisms of law no complex networks of rules, concepts and other related texts would have come into being. Writing down laws enables us today to research the Roman law and its language systematically. This is unique in the antiquity as other laws, especially the Greek are known only partly, mainly because of lack of documented sources and also due to the fact that the Greeks, while being aware of legal principles, limited themselves to creating laws of their polis (town). They did not create any overarching Greek law, unlike the Romans, who learned from the ancient Greeks the philosophical fundamentals of legislation (cf. Kaser and Knütel 2004: § 1. 3-11; Schulz 1961: 81). Textual analyses clearly show the interrelation between the Greek and the Roman law (cf. Girard 1923). Orality of legal practice was another element that makes our research into the laws of antiquity difficult. Legal certainty and legal doctrine become possible when law is written down, otherwise law is 
too complex to allow a system of intertwined argumentative rules to emerge and to remain in force. In the Roman law, no files from court proceedings exist beyond documents related to the court procedure such as opinions of legal experts. This makes impossible to reconstruct the argumentative mechanisms of the oral finding of law in antiquity. Sometimes, however, efforts to state the law might have been counterproductive in terms of its argumentative diversity. For instance, the Corpus Iuris Civilis as a compilation of texts streamlines the Roman law, yet it also neglects the rest of materials perceived by the compilers as useless. Legal linguists may wonder how easily the Byzantine compilers of the Corpus Iuris Civilis swept over texts stating their law of the past, with the result that many of these texts disappeared forever. Were the texts of the Roman law reduced to five per cent in the process of the compilation? (cf. Honoré 2010). The Byzantine compilation forces us to reconstruct the ancient Roman law from the quotes in the Corpus Iuris Civilis that is a paradox. Meanwhile, the very fact that we dispose of the sources of the Roman law enables legal linguists to deal systematically with issues of emergence and development of legal Latin. Many other legal-linguistic presuppositions are directly related to the Roman law. The ancient Romans maintained courageously that statutory law is positive law and that its setting is a political matter (cf. Honsell 1982: 148). Doubtless, the ancient Romans had other than linguistic concerns while stating their laws (cf. Härtel and Kaufmann 1991: 5). Meanwhile, we can understand their laws and ours only through their linguistic manifestations. It goes however without saying that the ancient Romans had their own goals for which their laws were construed. The science of the Roman law interprets and recognizes these often-hidden goals behind their linguistic manifestation. Mattila's research is instrumental in improving our understanding of such fundamental issues in the research of the Roman law through the focus upon the legal language. Mattila uses a nuanced approach to legal Latin that broadens our perspective upon unclear and only partly researched aspects of the legal Latin language.

The list of names of Polish researchers mentioned in Mattila's book is particularly long. I bring most names as they are also indicative of the research interest in legal Latin that is stronger in Poland than in most other countries. My incomplete list comprises: Ł. Biel, A. Dębiński, K. Gałuskina, J. Sycz, S. Grodziski, E. Longchamps de Bérier, A. Matulewska, A. Wasilewska, K. Pawłowski, J. Pieńkos, A. Plisecka, H. Sierocka, H. Święczkowska, A. Sokala, J. Sondel, 
A. Stępkowski, I. Szczepankowska, K. Szczygielski, P. ŚwięcickaWystrychowska, A. Tarwacka, W. Wołodkiewicz, J. Woźniak, and M. Zabłocka.

Professor Mattila's systematic approach to legal Latin provides a solid overview of research results in this area and structures the research area in a convincing way. Readers interested in legal Latin will benefit from reading Professor Mattila's book that is the result of his decades-long commitment to the researched subject matter.

\section{References}

Girard, Paul Frédéric. 1923. Textes de droit romain. 5th ed. Paris: Arthur Rousseau.

Härtel, Gottfried, Frank-Michael Kaufmann (eds.). 1991. Codex Justinianus. Leipzig: Reclam Verlag.

Honoré, Tony. 2010. Justinian's Digest: Character and Compilation. Oxford: Oxford University Press.

Honsell, Heinrich. 1982. Das Gesetzesverständnis in der römischen Antike. In Europäisches Rechtsdenken in Geschichte und Gegenwart. Festschrift für Helmut Coing zum 70. Geburtstag, vol. 1, Norbert Horn (ed.), 129-148. München: C.H. Beck.

Kaser, Max, Rolf Knütel. 2008. Römisches Privatrecht. Ein Studienbuch. 19th ed. München: C.H. Beck.

Mattila, Heikki E.S. 2002. De aequalitate Latinitatis jurisperitorum. Le latin juridique dans les grandes familles de droit contemporaines à la lumière des dictionnaires spécialisés. Revue internationale de droit compare vol. 3: 717-758.

Mattila, Heikki E.S. 2017. Vertaileva oikeuslingvistiikka. Juridinen kielenkäyttö, lakimieslatina, kansainväliset oikeuskielet. 2nd ed. Helsinki: Alma Talent.

Mattila, Heikki E.S. 2020. El Latín jurídico. Historia, uso internacional, problemas de comunicación. Santiago de Chile: Ediciones Jurídicas Olejnik.

Rezler, Jan. 1984. Język taciński dla prawników. Warszawa: PWN.

Schulz, Fritz. 1961. Geschichte der Römischen Rechtswissenschaft. Wien: H. Böhlaus Nachfolger. 
Tsou, Benjamin K., Andy Chin. 2021. Common Latin Terms in Hong Kong Legal Language. Hong Kong: Hong Kong University Press. 